\title{
Being human in the time of Covid-19
}

\begin{tabular}{|c|c|}
\hline $\begin{array}{l}\text { Author: } \\
\text { Johann-Albre }\end{array}$ & ht Meylahn ${ }^{1}$ (D) \\
\hline $\begin{array}{l}\text { Affiliation: } \\
{ }^{1} \text { Department } \\
\text { Theology, Fac } \\
\text { and Religion, } \\
\text { Pretoria, Pret } \\
\text { South Africa }\end{array}$ & $\begin{array}{l}\text { ff Practical } \\
\text { ulty of Theology } \\
\text { University of } \\
\text { ria, }\end{array}$ \\
\hline $\begin{array}{l}\text { Research Proj } \\
\text { Project Leade } \\
\text { Project Numb }\end{array}$ & $\begin{array}{l}\text { ect Registration: } \\
\text { r: J.A. Meylahn } \\
\text { er: } 02187133\end{array}$ \\
\hline $\begin{array}{l}\text { Description: } \\
\text { This research } \\
\text { research proj } \\
\text { practical post } \\
\text { theology as p } \\
\text { in response tc } \\
\text { challenges of } \\
\text { in contempor } \\
\text { Africa', direct } \\
\text { Prof. Dr Johan } \\
\text { Department P } \\
\text { Theology, Fac } \\
\text { and Religion, } \\
\text { Pretoria. }\end{array}$ & $\begin{array}{l}\text { is part of the } \\
\text { ct, 'Towards a } \\
\text { oundational } \\
\text { ublic theology } \\
\text { the } \\
\text { lived religion } \\
\text { ary Southern } \\
\text { d by } \\
\text { n Meylahn, } \\
\text { ractical } \\
\text { ulty of Theology } \\
\text { University of }\end{array}$ \\
\hline $\begin{array}{l}\text { Correspondin } \\
\text { Johann-Albre } \\
\text { johann.meyla }\end{array}$ & $\begin{array}{l}\text { gauthor: } \\
\text { ht Meylahn, } \\
\text { in@up.ac.za }\end{array}$ \\
\hline $\begin{array}{l}\text { Dates: } \\
\text { Received: } 07 \\
\text { Accepted: } 17 \\
\text { Published: } 30\end{array}$ & $\begin{array}{l}\text { Apr. } 2020 \\
\text { Apr. } 2020 \\
\text { Apr. } 2020\end{array}$ \\
\hline $\begin{array}{l}\text { How to cite th } \\
\text { Meylahn, J-A. } \\
\text { human in the } \\
\text { Covid-19', HT } \\
\text { Studies/Theo/ } \\
76(1) \text {, a6029. } \\
\text { org/10.4102/ }\end{array}$ & $\begin{array}{l}\text { is article: } \\
\text { 2020, 'Being } \\
\text { time of } \\
\text { Teologiese } \\
\text { gical Studies } \\
\text { https://doi. } \\
\text { its.v76i1.6029 }\end{array}$ \\
\hline $\begin{array}{l}\text { Copyright: } \\
\text { (c) 2020. The } \\
\text { Licensee: AOS } \\
\text { is licensed un } \\
\text { Creative Com } \\
\text { Attribution Lic }\end{array}$ & $\begin{array}{l}\text { uthors. } \\
\text { IS. This work } \\
\text { der the } \\
\text { nons } \\
\text { ense. }\end{array}$ \\
\hline Read online: & \\
\hline 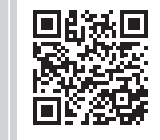 & $\begin{array}{l}\text { Scan this QR } \\
\text { code with your } \\
\text { smart phone or } \\
\text { mobile device } \\
\text { to read online. }\end{array}$ \\
\hline
\end{tabular}

The novel coronavirus - officially named severe acute respiratory syndrome coronavirus 2 (SARS-CoV-2), causing a disease (Covid-19) which has flu-like symptoms - seems to be responsible for the current global lockdown or maybe one can even refer to it as a global event. Neither the virus nor the disease that it causes is truly novel, as the virus is part of the SARS virus family and therefore known, and likewise the symptoms of the disease (Covid-19) are also well known, even flu-like, and therefore also not novel. Yet, what is truly novel about the virus or the disease it causes is its effect, not specifically referring to the health effect, but its global socio-economic and political effect. It is for the first time in the history of humanity that such drastic global lockdown measures have been taken and that governments have taken the conscious decisions to 'lay lame' (cripple) their economies. Such a radical decision is truly novel. Besides the economic 'lockdown', there are numerous socio-economic repercussions; for example, in a single day, millions (3.3. million) of citizens in the United States file for unemployment, and similarly in many other countries. Covid-19 is a challenge to the economies of the world, to society at large, to the poor and vulnerable in particular, and to individuals who are 'locked safely' in their homes. Religious institutions, which traditionally provide collective meaning, can no longer gather in public places, and offer communal solace. Covid-19 maybe challenges what being human means, or at least, what one has come to believe concerning the meaning of being human. In this article, this question of being human in the time of Covid-19 will be explored.

Keywords: Covid-19; Lacan; Public Theology; Pandemic; Subjectivity.

\section{Waking up to Covid-19}

One morning, after being woken by a bad dream, I lay awake and had the beautiful opportunity to listen to an owl hooting to another in our garden. This amazing and reassuring sound was in such stark contrast to the nightmare and the nightmarish days reported on in the media. The sound helped me to realise that the birds in our garden and the animals in my world (our dog and our cat) do not have a care about this so-called global event or global lockdown. On the contrary, they seem to be enjoying our extended and continuous presence at home. This relativising realisation awoke more intensely in me the desire to understand what this Covid-19 is, and why it is disturbing so much to 'normal' life, at least normal human life, because other life as such seems to continue undisturbed? Some are arguing that Life (with capital L) is making a comeback because of the lockdown, ${ }^{1}$ or at least Life seems to be exhibiting signs of better quality, as oceans, rivers and air are believed to be cleaner. Whatever this Life is that is presumed to now have a better quality, one cannot deny the persistent question: for whom does it have this socalled better quality? The question of the quality of life is often the question of the privileged, as many are now suffering more than ever because of a lack of income, lack of medical care and lack of family and social support. These differing opinions about the quality of life, which is so easily relativised by the question of equality, already reveal (if anything is revealed) that it is indeed a human problem. It is a human problem not only because it is a virus, as one has been told, that attacks (for now) specifically humans, but because humans are epidemic, ${ }^{2}$ and this because of language and its viral nature. I will argue that it is maybe the epidemic nature of language that has made (created) Covid-19 a global pandemic, and thus a global event. Maybe Covid-19 even has the makings of a possible truth event (Badiou 2011) that ushers in the possibility of a new world. In that sense it can be seen to be metaphysical as it creates a new time-space, which many are concretely experiencing in their locked-down homes: a new sense of time and space.

1.https://www.theguardian.com/environment/2020/mar/20/nature-is-taking-back-venice-wildlife-returns-to-tourist-free-city.

2.The human being is epidemic because he or she speaks and is inhabited by that enjoying substance that we call the signifier (Lacan 1998:24). 


\section{Natural phenomenon?}

Covid-19 as a 'natural' phenomenon seems to stringently obey the laws of 'nature' at least in accordance with how biology spells out these laws. Experts (scientists) seem to know everything about this virus. They have identified patient zero, and know precisely how it enters the human body, how it is transmitted, the rate at which it transmits, how long it incubates and what it then does within the human body. Because of this knowledge, humanity has been given exact instructions: how far to stand from each other, for how long to self-isolate if infected and so on. So, currently there is an overload of information (knowledge) and this knowledge is at one's fingertips because of the Internet and smart phones. This accessibility has millions following worldometers, ${ }^{3}$ with the possibility of tracking the number of infected and number of deaths by country as if it has become a macabre global competition. There is no lack of knowledge, fake or real.

If we have all this knowledge, meaning and sense literally at our fingertips, then why is Covid-19 such a traumatic event, if trauma is understood in terms of there being lack of meaning and sense?

Covid-19 is a viral disease; it is also a socio-economic crisis and therefore political crisis, which has transformed it into a global event, but what makes it so novel? Adam Tooze (2020) argues that what is novel about the virus and the disease is the radical economic decisions of Western economically powerful governments to 'close' their economies down:

Nicht der Virus an sich, nicht die Pandemie ist einmalig - das hat es natürlich schon gegeben -, aber der bewusste Versuch aller größeren Staaten, ihre Wirtschaften lahmzulegen, ist in dieser Form Neu. (Tooze 2020:2-4)

The virus is not new, the pandemic is not new, but the conscious decision of governments to 'cripple' their economies is new.

Trauma is normally understood as something that cannot be signified and that defies meaning; however, Covid-19, if anything, is overloaded with meaning. There is no hole (lack) in human knowledge. Covid-19 is perhaps even experienced to be so traumatic because of the information overload and that humans are struggling to deal or cope with.

The coronavirus is biologically described as a virus, nondead something, a single-stranded molecule (RNA), that attacks or rather attaches itself to the double-stranded molecule (DNA) of a host and in the process transforms the DNA of the host, making the host sick - in terms of a certain definition of health. I say 'non-dead' because a virus is not a living organism, but neither is it dead, in the sense that it has effects, and these effects spread at an exponential rate - which one has been told numerous times by both experts and the moral police on social media who warn everybody not following the orders (the laws of the state of emergency/ disaster or state of exception) of the exponential consequences of their actions.

3.https://www.worldometers.info/coronavirus/.
What is traumatic and novel about Covid-19 is not its medical (health) or even 'natural' implications as these are well known. Its traumatic and novel nature seems to lie elsewhere.

\section{Covid-19 and the real}

The lack of meaning or knowledge or naming is not what is traumatic because science has already clearly spelled out all the knowable details and given names to it. It is also the scientists who seem to have given the political leaders of numerous countries all the details regarding the spreading of the virus, and more specifically how this spreading can be slowed down, the famous 'flatten the curve!'. They also seem to be unanimous that $60 \%-80 \%$ of the population will get this virus, but only a small percentage will become seriously ill and will, therefore, need hospitalisation. However, to prevent overtaxing of the hospitals, this curve of infections needs to be slowed down so that the hospitals and caregivers can cope. This seems to be the current dominant story concerning the response to Covid-19.

This dominant narrative is based on the knowledge provided by science, and currently good political leadership is measured on a scale of how far the leaders are obedient to science, as once in the past good leadership was measured in how far leaders were obedient to religious leaders or spiritual leaders. One could ask, why politicians have now listened to science with such precision, when in the past (thinking specifically of the climate scientists) this was not always the case?

As a result of all this information and 'good' leadership, one finds oneself now confined to one's home with the everwatchful eyes of over-conscientious neighbours only too ready to report on a local WhatsApp group, any 'illegal' walking or jogging. Most of these neighbourhoods, who are privileged to have community WhatsApp groups, are extremely safe as they always keep a fair amount of social distance and are therefore in stark contrast to other neighbourhoods where lockdown is physically impossible because of time and space constraints, as in these neighbourhoods the 1.5-m or 2-m rule no longer makes sense, and cannot apply to individuals as it does not even apply to the distance between dwellings. In these settlements, nobody can stock up on essential food items, either for lack of space or, more importantly, for lack of cash. Washing hands from a running tap is not possible as there is no running water in every home, but only communal taps where social distance again is problematic. They cannot work from home and continue to earn their salary, as their income, if any, came from being day labourers who are now prevented from working and therefore also prevented from earning an income. Should earning a living not also be recognised as essential work? What is essential work or what is 'system relevant' (see Tooze 2020) seems to be a new burning question, to which one needs to add the question: which system? What is relevant to save the system? In 2008, it was the banks that needed to be saved to save the system; today it is various forms of what has been classified as essential work, but which system is being saved? The same system that over the 
past few decades, under the ideology of austerity, did not recognise what today is seen as essential for the system, by keeping the wages of 'essential' workers at a system minimum and cutting this 'essential' work to a minimum.

This is where the crisis is and maybe where the real of the virus can be found, that is, if it exists. If it (the real of the virus) is to be found, then it can be found in the too many questions for which neither science nor the dominant ideology has any answers. The virus, the viral effects named Covid-19, is challenging the dominant ideology.

This becomes clear in the numerous articles that have recently appeared in the media, some of which are academic (which is supposed to mean scientific) and others more popular, on the effects of Covid-19 on the poor, on the economy, on the possible rise of domestic violence, the rise in depression and suicide rates, and so on. This 'virus' has caused, if one can say so, a hole, not with regard to knowledge concerning the virus, as one has too much information about it, but it has caused a hole, a lack, in the dominant symbolic-imaginary world, for example, a hole in the global symbolic world of neoliberal finance capitalism (see Lapavitsas 2020), and there are some who are predicting the end of this ideology because of this crisis (see Cherkaoui 2020). It has caused a hole in the public versus private healthcare debate, the social debate concerning the elderly and the vulnerable. Closer to home for many, it has caused a hole in one's normal social life by being forced to stay home and no longer meet at restaurants and bars for a drink and a chat, going to the gym, walking the dogs, ordering food via Uber and having friends over for dinner

Covid-19 has caused a hole, or a lack has appeared in the symbolic and the imaginary. Lacan describes this lack as the real (see Žižek 2008:8). Does this make the virus the real? No, because the virus itself does not lack meaning or knowledge, but it has caused, if one can speak of cause, a lack in the symbolic and imaginary worlds one lives in. One is forced to imagine oneself anew. It has not caused a hole, a lack, to appear, but it has exposed the lack, the hole, that was there all the time, but because one was so busy 'living' the semblance (in the system), one was not aware of it. The virus has caused a certain awareness of the hole in the semblance, but it is not the hole.

The lack has caused a disruption, and many have scrambled, literally scrambled, to fill this lack with new meaning, both religious and political, thereby wishing to repair the semblance. Or as Badiou (2011:339ff.) would argue, truth events are in science, art and politics. He leaves out religion, which I would add. This scramble to fill the lack, to 'cure' the lack, is the task of religion, or that is what religion is designed for, according to Lacan (see Lacan 2013a:71ff.). The number of sermons that have appeared on the Internet (YouTube), and not just on the websites of various congregations, seems to be an indication of this religious design to provide meaning and sense. Likewise, social media is littered with those who imagine themselves messianic leaders of a new political movement that can emerge from this crisis, offering new meaning and even the dream of a new city to come - with their specific brand of ideology, religion or 'return to nature'. Covid-19 has caused a scramble - religious, political, scientific and artistic - to transform the lack into a new truth.

This is not a critique, even if it might sound as such, but it is perhaps an indication of what it means to be human. This is maybe what humans do: they create religious, scientific, artistic and political-ideological fictions in response to the real, in response to the lack within their symbolic and imaginary. To be human in the time of Covid-19 maybe brings into full view this characteristic of what it means to be human: the frantic scramble for meaning in response to the lack, in response to the real. There is no ultimate meaning except the meaning that one imagines oneself finding in that one creates it from the great fund of symbolic resources of the past, present and future of the symbolic worlds one lives in.

\section{Being human}

So, what to do when one is a human in a time of Covid-19, which is so different from the owls hooting in my garden? Should one join the frantic scramble to provide 'new' meanings, via religion, science, politics or art? Or should one claim the moral or ethical high ground with regard to particular identified groups who are identified as most affected or most vulnerable, and then imagining oneself as the saviour or hero of the poor and vulnerable?

The problem is not all the different meanings that are provided - religious, political, scientific or artistic - as that would be maybe the 'natural' human response. The problem is the belief and conviction that is invested in these differing meanings, which inevitably leads to antagonism.

This 'natural' human response was exactly also what I did: I watched, read and listened with glee various 'respected' (in my view) opinions, for example, Yanis Varoufakis from DiEM 25, ' $[t]$ he coronavirus is going to accelerate the post 2008 crisis', ${ }^{4}$ and likewise enjoyed the little video A letter from the virus, ${ }^{5}$ to name but a few. I find myself strangely satisfied (justified) when reading articles and posts that claim that Corbyn and Sanders were correct with their policies and that most of these policies will now be implemented by Republican and Tory governments (see Peat 2020). I cannot help watching, reading and listening to these opinions and not wishing it were true: that there is a clear solution, and it is only a matter of finding enough faithful subjects (Badiou 2009:62ff.) who would respond to this event and thereby transform the world in accordance with this newfound (actually created) truth.

This is the human thing to do and perhaps a good thing to do: to seek alternative and better systems (symbolic-imaginary systems) when the current system is showing cracks. However, the moment one says better, on whose or what criteria does one base such a claim? There are indeed better and worse systems, and one possible criterion whereby to 4.https://www. filmsforaction.org/watch/yanis-varoufakis-the-coronavirus-is-goingto-accelerate-the-post-2008-crisis/.

5.https://www.filmsforaction.org/watch/a-letter-from-the-virus-listen/. 
judge could be the idea of equality and quality of life for the greater majority.

These ideas by which to judge have formed the basis of ethics for many centuries whereby systems can be judged. The above criteria would most probably be my criteria for judging systems, but who am I to establish such criteria? My criteria would be based on what speaks to my particular imagination inspired by my specific symbolic heritage, for example, the idea of nature being and remaining in control, like the metaphysical Gods of old, speaks to my symbolic inspired imagination. Thus, the criteria for judgement depend largely on the symbolic world one was born into. Therefore, within certain symbolic systems there are probably better systems and to strive towards these systems might be an honourable and good thing to do in these times. Instead of being antagonistic about these differing systems imagined by different symbolic systems one could maybe move towards agonism, as Mouffe (2013) suggests.

This is maybe the human response: to imagine a new symbolic world, or an improved symbolic world, a new world order that is perhaps more just.

\section{The church and Covid-19}

What about the church in the times of Covid-19? The church's response, specifically taking the various posts on social media into consideration, could be interpreted as a typically state church response: do as the government says but add a little mercy and charity, and that would be your Christian responsibility. Stay at home, do not go to church, but reach out via social media or financially to those in greater need than yourself.

Again, this is a very honourable thing to do and certainly something worth striving towards.

What Covid-19 certainly has done: it has exposed a crisis, not necessarily a crisis in health, as many health experts argue that Covid-19 is milder than the common flu, but a crisis in our economic and political dominant symbolic imagination. Or it is being used as a necessary crisis in the economic and political dominant symbolic imagination for purposes that will probably only reveal themselves after the event, as Klein (2008) has explained the political (capitalist) use of disasters and crises in the past. Covid-19 has exposed a crisis that has been there for some time, according to Varoufakis (2020); it has been there at least since the financial crisis in 2008. The crisis has probably always been there, as it is the crisis of the symbolic (real) to which the symbolic and the imagination continually respond by seeking effective defences. The symbolic is always in crisis; it perpetually needs to re-create itself as a defence against the believed real of the symbolic.

Covid-19 has exposed this crisis, and the created (named) crisis is being used, without falling into the trap of one or other hair-raising conspiracy theory, but yes indeed it is being used by various powers to turn the tide of this crisis to their advantage, and who would not try and do that? Various powers - even the power of the powerless - is being used to take advantage of this crisis to either change the systems, for example, the dream of a socialist revolution (and 'Bernie Sanders was right all along!') (see Pierson 2020) or to change the laws so as to continue to benefit or save the few. This is the politics of crisis - again a very human response.

I still have not answered the question of what one should do as human in the context of Covid-19. The term 'should' is an interesting word, as if one could clearly and singularly answer this question with a normative 'should!' Maybe the question can be posed more openly: what can one do? Well, do the only thing that probably can be done: be human. Create fictions to your own and others' benefit. Create poiessis, a good fiction, maybe even an inclusive fiction, a quality of life fiction, but do not forget that it is a fiction. Be creative by creating a new polis, a new city; create a new politics that seeks to be as inclusive as possible, remembering that it is not possible to be all-inclusive. Create an alternative, maybe like DiEM25 and Yaroufakis, or the idea of a possible return of nature as the letter from the virus suggests, but do not think that it is the truth or the real, as it remains a response to the real and as response a defence against the real, as all responses in the past, present and future were and will be.

All these responses (defences) form a strange unwilled democracy of fictions, where the different fictions are equal in being equally fictions. Likewise, the criteria for judging between the different fictions are based on fictions - as these criteria are based on the creation of various Names of the Father (see Lacan 2013b), in whose name one can judge.

If all these Names (of the Father) are crucified in their incarnate embodiments (exposed as being fictions), then something of a strange democracy of resurrection can emerge: the democracy of fictions (see Meylahn 2018:219ff.).

It is in the absolute freedom, with no name of any Father, no Other of the Other (see Lacan 2016:43), that one can create something truly novel, and in this novel creation something of the resurrection becomes tangible.

That might be the calling of the Christians in this time. The calling cannot be to be or become the moral voice of the state, or the moral voice of the lockdown, with a few pastoral hacks on how to survive it, or a few ethical tips of how to be a good locked-down Christian. I am sure that it is wonderful to do all these things, and there might even be something honourable in it, but would there not be consensus that such behaviour is what is expected of any civilised human being (see Mt 5:47)? So, to do all these honourable things might be a decent human thing to do, but not necessarily a specifically Christian calling.

\section{A Christian response to Covid-19}

What would or could be a specifically Christian calling or response in a time of Covid-19? Well, from the text I was 
hinting at previously (Mt 5:47), the uniquely Christian thing do to is to love enemies - which would cause a dissensus (see Rancière 2019:108) in the consensus of civilised things to do. This text raises the question: who exactly is the enemy at such a time? The dominant enemy for some seems to be all those who still go jogging in the streets and walk their dogs in defiance of the lockdown rules, namely, those who do not take this lockdown seriously. From social media the enemy seems to be all those who are so self-centred that they only think of themselves and not of the vulnerable they might infect with their defiance of the lockdown laws. Governments in their rhetoric, on the contrary, seem to view the virus as the enemy (see Hunter 2020).

The enemy is not the one that does wrong by disobeying the law, that would make them criminals but not the enemy. The enemy is the one who could destroy the polis, or at least is needed to create the polis according to Schmitt (see Derrida 2005:84; Meylahn 2018:123 \&153; Mouffe 2013:5), the one who could destroy one's religion, one's consensus, that which can destroy one's collective semblance, the one that could destroy one's symbolic imaginary. The enemy is not the one who contravenes the law, but who destroys the law, blasphemes the Name (the No/Law) of the Father. The enemy is the one who challenges the consensus of the norm of the polis. This is the kind of enemy that Christians are called to love. The Christian challenge is to love this lawdestroying enemy, who can destroy one's polis, one's semblance of oneself and the world. If I love that which can destroy my world, then one can witness the birth (rebirth) of a racially democratic polis. From the crisis (crucifixion), witness the birth of a new world, where there is neither Jew or Greek, man or woman, free or slave (Gl 3:28) (all the different fictions that had given one a place in one's world). That is the challenge: to create spaces for such crucifixion and the resurrection of a democracy of fictions, where all the different ideologies, religions, scientific theories, artistic creations, morals and ethics are all equally valid and invalid as they are equally fictional. All these differing fictions are not collected under a new meta-fiction of tolerance or inclusion and thus create a politically correct multi-cultural ideology, but the agonism of these differences is carried without sublimation into one or other metanarrative.

Maybe that could be a gospel, Euangelion [good news] to proclaim in these times, as it gives one the freedom to imagine a completely new world, and therein lies the hope of the faithful. A new world where lion and lamb can lie together and the little child can play at the snake's nest (Is 11:6), or Jew and Greek can be together, not because lions are no longer carnivores, or because Jews and Greeks are the same, but because classifications and stratifications on which identity and subjectivity are based have been exposed as necessary but insufficient fictions. It is not that the differences have been sublimated into a new metacategory, but it is their failure, their lack, wherein lies the grace of a new world. It is their insufficiency and their failure (crucifixion) wherein lies the hope.

\section{Acknowledgements Competing interests}

The author has declared that no competing interest exist.

\section{Author's contributions}

I declare that I am the sole author of this research article.

\section{Ethical consideration}

This article followed all ethical standards for a research without direct contact with human or animal subjects.

\section{Funding information}

This research received no specific grant from any funding agency in the public, commercial, or not-for-profit sectors.

\section{Data availability statement}

Data sharing is not applicable to this article as no new data were created or analysed in this study.

\section{Disclaimer}

The views and opinions expressed in this article are those of the author and do not necessarily reflect the official policy or position of nay affiliated agency of the author.

\section{References}

Badiou, A., 2009, Logics of worlds: Being and event, 2, transl. A. Toscano, Continuum, London.

Badiou, A., 2011, Being and event, transl. O. Feltham, Continuum, London.

Cherkaoui, M., 2020, 'The shifting geopolitics of coronavirus and the demise of Neoliberalism', Aljazeera, 22 March 2020, viewed 02 February 2020, from https:// studies.aljazeera.net/en/reports/shifting-geopolitics-coronavirus-and-demiseneoliberalism---part-2.

Derrida, J., 2005, The politics of friendship, transl. G. Collins, Verso, London.

Hunter, D., 2020, 'Coronavirus: If we are in a war against COVID-19 then we need to know where the enemy is', The Conversation, 01 April 2020, viewed 02 April 2020,
from http://theconversation.com/coronavirus-if-we-are-in-a-war-against-covidfrom http://theconversation.com/coronavirus-if-we-are-

Klein, N., 2008, The shock doctrine: The rise in disaster capitalism, Picador, New York, NY.

Lacan, J., 1998, The Seminar, Book XX, Encore, J.-A. Miller (ed.), transl. B. Fink, W.W. Norton, New York, NY.

Lacan, J., 2013a, The triumph of religion preceded by discourse to Catholics, transl. B. Fink, Polity Press, Cambridge.

Lacan, J., 2013b, On the names-of-the-father, transl. B. Fink, Polity Press, Cambridge.

Lacan, J., 2016, The sinthome: The seminar of Jacques Lacan, Book XXIII, J.-A. Miller (ed.), transl. A.R. Pice, Polity Press, Cambridge.

Lapavitsas, C., 2020, 'This crisis has exposed the absurdities of Neoliberalism. That doesn't mean it'll destroy it', Jacobin, 27 March 2020, viewed 02 April 2020, from https://jacobinmag.com/2020/3/coronavirus-pandemic-great-recessionneoliberalism.

Meylahn, J.-A., 2018, Trans-fictional praxis: A Christ-poiēsis of imagining non-colonial worlds emerging from the shadows of global villages, Lit Verlag, Zürich.

Mouffe, C., 2013, Agonistics: Thinking the world politically, Verso, London.

Peat, J., 2020, 'Boris Johnson will have to adopt some very socialist principles "whether he likes it or not"', The London Economic, 17 March 2020, viewed 02 April 2020, from https://www.thelondoneconomic.com/politics/boris-johnsonwill-have-to-adopt-some-very-socialist-principles-whether-he-likes-it-ornot/17/03/.

Pierson, C., 2020, 'Too late, coronavirus proved Bernie Sanders was right. Now we have to settle for a recession led by Biden' Independent, 24 March 2020, viewed 02 April 2020, from https:/wwwindependent.co.uk/voices/coronavirus-bernie02 April 2020, from sanders-biden-medicare-for-all-wheresjoe-wedeservebernie-a9421471. html?fbclid=IwAR3phjo_mg2muLjQoNB3X4AMG5xrE8wBJothBWN3CMty1XdqW
gs9U-thOVs. 
Rancière, J., 2019, Dissensus: On politics and aesthetics, ed. and transl. S. Corcoran, Bloomsbury Academic, London.

Tooze, A., 2020, 'Wirtschaftshistoriker über Finanz- und Coronakrise "Wir erleben etwas radikal Neues"', Adam Tooze im Gespräch mit Dieter Kassel, interview 31, March 2020, viewed 02 April 2020, from https://www.deutschland funkkultur.de/wirtschaftshistoriker-ueber-finanz-und-coronakrise-wir.1008.de. html?dram:article id $=473684$.
Varoufakis, Y., 2020, 'The coronavirus is going to accelerate the post $2008 \mathrm{crisis}$ ', Films for Action, viewed 02 April 2020, from https://www.filmsforaction.org/watch/ yanis-varoufakis-the-coronavirus-is-going-to-accelerate-the-post-2008-crisis/.

Worldometers, Coronavirus cases, viewed 02 April 2020, from https://www. worldometers.info/coronavirus/.

Žižek, S., 2008, 'The Lacanian real: Television', The symptom, 9 Fall 2008, viewed 02 April 2020, from https://www.lacan.com/symptom/the-lacanian.html. 